\title{
A Synthesis of Empirical Research on the Validity of Wagner's Law
}

\author{
Dimitrios Paparas ${ }^{1}$, Christian Richter ${ }^{2}$
}

\begin{abstract}
In this paper we provide a synthesis of empirical research in the validity of Wagner's law of the existing literature for the period 1969-2014. Wagner's law attracted the interest of many authors and is still being discussed by policy makers and economists in relation to government spending expansion since it was applied by Adolph Wagner in the 1880s. There are two different hypotheses about the expansion of state activity. Firstly, the size of government activity is tested in endogenous growth models, while the second suggest that the economic activity is exogenous to the economic growth (Keynesian view). Additionally, we will present the previous empirical work in this topic. Since the translation of Wagner's "law" in 1950's, a large number of authors tested various specifications of the law. These studies used both time series and panel data sets and empirically examined the law for a single country and for a group of countries (multi-country studies). Furthermore, there are studies using data on government expenditure at the provincial or state level. Existing studies in this topic vary in the country selection. They used data for developed, developing countries or group of both, while most of them examined developed or industrial countries. Finally, there are studies examined the Wagner's against Keynesian hypothesis. All these studies found different empirical results: support, no support or mixed results. Conflicting findings in this field are not surprising because of the diverse theoretical predictions and also because countries may be at different stages of economic development; thus, the debate about the relationship between government spending and economic growth remains an unresolved issue.
\end{abstract}

Keywords: Wagner's' Law, Causality Tests, Greece, Long Run Time Series Analysis

JEL Codes: A10, E6, H3, H4, I3, N1

\section{Introduction}

The relationship between government spending and national income is very important for many economic and policy issues. Nowadays European Countries are in recession and government authorities have to stimulate their economies through extra fiscal measures. The government

\footnotetext{
${ }^{1}$ Land, Farm and Agribusiness Management Department, Harper Adams University, U.K.

Email:dpaparas@harper-adams.ac.uk

${ }^{2}$ German University in Cairo, Faculty of Management Technology, Egypt.
} 
spending and national output relationship is also crucial for the sustainability of public deficits, thus the detection of this relationship will provide a theoretical and empirical framework which can be used in order for governments to succeed in the budgetary objectives. As we mentioned, the relationship between government spending and economic growth is one of the most debated issues among economists during the last decades (Bird, 1971; Musgrave, 1969;Courakis et al.,1993; Gandhi, 1971; Oxley, 1994; Mann, 1980; Lin, 1995; Paparas et al., 2015a; Paparas et al., 2015b; Paparas and Richter, 2018; Richter and Paparas, 2013b). It is an old issue of classical economics and many economists (Landau 1983, Barro and Sala-I-Martin, 2004; Folster and Henrekson, 2001) claimed that the growth of government spending has a significant negative impact on economic growth of a country and the state activities are required to be kept on the least possible.

Many studies have investigated the relationship between government spending and economic growth across countries (Kolluri and Wahab, 2007; Shelton, 2007; Karagianni et al., 1998). A strand of literature examined the determinants of the size of government by focusing on alternative explanations such as per capita income (Borcherding, 1985) or focusing on the relative price of government provided goods and services (Baumol, 1967), on demographic factors (Heller and Diamond 1990), or the size (Alesina and Wacziarg,1998) or finally the degree of openness of the economy. Another branch investigated the relationship between expenditure and economic growth over time (some studies focused on the description of long-run tendencies). Finally other studies (Bird, 1971; Georgakopoulos and Loizides, 1994) attempted to estimate the elasticity of government expenditure with respect to output and tried to find evidence of the empirical test called "Wagner's law", the hypothesis that government spending increases more than proportionally with higher economic activity.

One reason of having this study is the extensive debate among economists involving the impact of government spending and taxation on economic growth across different countries. Focusing on the relationship between government spending and economic growth we will examine studies that investigated the validity of Wagner's law. If the law is valid, it will allow the government authorities to reduce the government spending. Therefore, the budget deficits will be reduced and the expanding role of the private sector in the economy will be promoted. On the other hand, if government spending has a significant impact on growth, government authorities and policy makers have to recognize the crucial role of spending on economic growth.

There have been several studies, including some meta-analyses, of the macroeconomic effects of various government spending categories, including government consumption, military, education, infrastructure and total government expenditure (see, e.g.,Alptekin and Levine, 2012;Awaworyi Churchill et al., 2017; Bergh and Henrekson, 2011;Nijkamp and Poot, 2004); but unpredictably, much less research has been done on the validity of Wagner's Law. To the best of our knowledge, this paper is the first to provide a detailed empirical synthesis of the validity of Wagner's law.

Poot (2000) made a synthesis of the 1983-98 published literature on the empirical evidence regarding the interaction between government policies and growth. He suggested that a better link with current theories will be obtained when parameter calibration methods for micro-foundations based models replace parameter estimation of regression models with ad hoc specifications. Better data are needed at the regional macro and meso levels to complement the currently available pooled cross-section time-series country data. The potential endogeneity of government fiscal variables can be resolved through the selection of appropriate instrumental variables, such as those that arise in cases of "natural experiments". 
Conflicting findings in this field are not surprising because of the diverse theoretical predictions and also because countries may be at different stages of economic development; thus, the proportion of GDP spent on government spending may vary over time and between countries. In addition, model specification as well as estimation methods differ between studies. Thus, the debate about the relationship between government spending and economic growth remains an unresolved issue.

\section{Versions of Wagner's law}

According to Dutt and Ghosh (1997), Wagner did not present any mathematical form in order to examine his hypothesis and he also was not explicit in the formulation of his hypothesis. However, there are several versions that tested the Wagner's hypothesis and the most important of them are the followings: Peacock and Wiseman(1961), Gupta (1967), Goffman (1968) , Goffman and Mahar (1971), Pryor (1969), Musgrave (1969), Mann (1980) and finally Florio and Colautti (2005). These different interpretations include different measures of spending or national income and include different functional form of the relationship between state activity and income. Finally, they have different limits of the state activity, or they do not have any limits at all.

The first version was constructed by Peacock and Wiseman (1961), while subsequent authors made changes in their original form. None of the seven versions have included the regulatory activity in their analysis. Only Florio and Colautti (2005) recognized and attempted to analyse the limits of fiscal expansion. All versions, except Gupta (1967) and Florio and Colautti (2005), tested the linear relationship between spending and national income in levels or logs. Gupta (1967) presented a nonlinear model because he believed that this provides enhanced explanations of the Wagner's hypothesis and it is easier to understand the relationship between spending and income over time across different countries.

Many authors however, recognise that the traditional formulation of the law is quite simplistic. Economic development is a very complex process and cannot be represented only from a single index; many factors (economic and non-economic) can affect the expansion of public activities. Some of these factors, such as technological advances, are qualitative in nature and therefore cannot be easily quantified. On the other hand some of them can be quantitatively introduced to the model by quantifiable variables or by dummies. Two very good examples that can be possible variables of longrun evolution of government activity are given by Georgakopoulos et al. (1992), such as population size and the political attitudes of the party in power.

\section{A Synthesis of the empirical literature}

Since the translation of Wagner's "law" in 1950's, a large number of authors tested various specifications of the law. These studies used both time series and cross-sectional data sets and empirically examined the law for a single country and for a group of countries (multi-country studies). Finally, there are studies using data on government expenditure at the provincial or state level. Existing studies in this topic vary in the country selection. They used data for developed, developing countries or group of both, while most of them examined developed or industrial countries. However, during the last 5 years there are an increased number of studies examining the case of developing countries from Africa and South Asia. Table 1 includes 113 studies that examined the Wagner's law containing information about: Name of author, year of publication, tested period, type of analysis, 
type of methodology and main conclusion for the validity of the law. In the next section we will analyse the different methodologies, analyses and results.

Table 1: Survey in previous studies examined Wagner's Law

\begin{tabular}{|c|c|c|c|c|c|c|}
\hline No & Author & Country & Time period & $\begin{array}{l}\text { Type of } \\
\text { Analysis }\end{array}$ & Methodology & $\begin{array}{l}\text { Main } \\
\text { results }\end{array}$ \\
\hline 1 & Lall (1969) & $\begin{array}{l}46 \text { developing } \\
\text { countries }\end{array}$ & 1962-1964 & Panel data & Ordinary Least Squares & No support \\
\hline 2 & Bird (1971) & Canada & $1933-1965$ & Time series & Ordinary Least Squares & Support \\
\hline 3 & Gandhi (1971) & $\begin{array}{l}25 \text { African } \\
\text { countries }\end{array}$ & $1960-1965$ & Panel data & Ordinary Least Squares & No support \\
\hline 4 & $\begin{array}{l}\text { Goffman and Mahar } \\
\text { (1971) }\end{array}$ & $\begin{array}{l}6 \text { Caribbean } \\
\text { countries }\end{array}$ & $1940-1965$ & Time series & Ordinary Least Squares & No support \\
\hline 5 & Thorn (1972) & 52 countries & $1952-1962$ & Panel data & Ordinary Least Squares & Support \\
\hline 6 & Michas (1974) & Canada & $1950-1961$ & Panel data & Ordinary Least Squares & Support \\
\hline 7 & $\begin{array}{l}\text { Wagner and Weber } \\
\text { (1977) }\end{array}$ & 34 countries & $1950-1972$ & Time series & Ordinary Least Squares & No support \\
\hline 8 & Man (1980) & Mexico & $1913-1958$ & Time series & Ordinary Least Squares & $\begin{array}{l}\text { Mixed } \\
\text { results }\end{array}$ \\
\hline 9 & Ghamdi (1983) & Saudi Arabia & $1960-1981$ & Time series & Ordinary Least Squares & Support \\
\hline 10 & Singth and Sahni (1984) & India & $1950-1981$ & Time series & Ordinary Least Squares & No support \\
\hline 11 & $\begin{array}{l}\text { Ablzabeh and Gray } \\
\text { (1985) }\end{array}$ & 55 countries & $1963-1976$ & Panel data & Ordinary Least Squares & $\begin{array}{l}\text { Mixed } \\
\text { results }\end{array}$ \\
\hline 12 & Vatter and Walker (1986) & U.S.A. & $1929-1979$ & Time series & Ordinary Least Squares & Support \\
\hline 13 & Ram (1986b) & 63 countries & $1950-1980$ & Panel data & $\begin{array}{l}\text { Ordinary Least Squares, } \\
\text { Granger causality }\end{array}$ & Support \\
\hline 14 & Afxentiou (1986) & Cyprus & $1960-1982$ & Time series & Ordinary Least Squares & $\begin{array}{l}\text { Mixed } \\
\text { results }\end{array}$ \\
\hline 15 & Ram (1987) & 115 countries & $1950-1980$ & Panel data & Ordinary Least Squares & $\begin{array}{l}\text { Mixed } \\
\text { results }\end{array}$ \\
\hline 16 & $\begin{array}{l}\text { Abizadeh and Yousefi } \\
\text { (1988) }\end{array}$ & U.S.A & $1950-1984$ & Time series & Ordinary Least Squares & Support \\
\hline 17 & Kolluri et al. (1989) & 6 countries & $1960-1985$ & Time series & Ordinary Least Squares & Support \\
\hline 18 & $\begin{array}{l}\text { Nagarajan and Spears } \\
\text { (1990) }\end{array}$ & Mexico & $1950-1980$ & Time series & Ordinary Least Squares & Support \\
\hline 19 & Khan (1990) & Pakistan & $1959-1984$ & Time series & Ordinary Least Squares & Support \\
\hline 20 & Gyles (1991) & U.K. & $1946-1985$ & Time series & Ordinary Least Squares & Support \\
\hline 21 & $\begin{array}{l}\text { Georgakopoulos et al. } \\
\text { (1992) }\end{array}$ & U.K. & $1954-1983$ & Time series & Ordinary Least Squares & No support \\
\hline 22 & Ram (1992) & OECD countries & $1950-1985$ & Time series & Ordinary Least Squares & Support \\
\hline 23 & $\begin{array}{l}\text { Yousefi and Abizadeh } \\
\text { (1992) }\end{array}$ & U.S.A. (30 states) & $1950-1985$ & Time series & Ordinary Least Squares & Support \\
\hline 24 & Bairam (1992) & OECD countries & $1950-1985$ & Time series & Ordinary Least Squares & $\begin{array}{l}\text { Mixed } \\
\text { results }\end{array}$ \\
\hline 25 & Henrekson (1993) & Sweden & $1861-1990$ & Time series & $\begin{array}{l}\text { Cointegration, Granger } \\
\text { Causality }\end{array}$ & No support \\
\hline 26 & Courakis et al. (1993) & $\begin{array}{l}\text { Greece and } \\
\text { Portugal }\end{array}$ & $1958-1985$ & Time series & Ordinary Least Squares & No support \\
\hline 27 & Murthy (1993) & Mexico & $1950-1980$ & Time series & $\begin{array}{l}\text { Cointegration, Granger } \\
\text { Causality }\end{array}$ & Support \\
\hline 28 & Murthy (1994) & Mexico & $1950-1988$ & Time series & $\begin{array}{l}\text { Cointegration, Granger } \\
\text { Causality }\end{array}$ & Support \\
\hline 29 & Ashworth (1994) & Mexico & $1950-1988$ & Time series & $\begin{array}{l}\text { Cointegration, Granger } \\
\text { Causality }\end{array}$ & No support \\
\hline 30 & Hayo (1994) & Mexico & $1950-1980$ & Time series & $\begin{array}{l}\text { Cointegration, Granger } \\
\text { Causality }\end{array}$ & No support \\
\hline 31 & $\begin{array}{l}\text { Georgakopoulos and } \\
\text { Loizides (1994) }\end{array}$ & Greece & $1953-1991$ & Time series & Ordinary Least Squares & No support \\
\hline 32 & Oxley (1994) & Britain & $1870-1913$ & Time series & $\begin{array}{l}\text { Cointegration, Granger } \\
\text { Causality }\end{array}$ & Support \\
\hline 33 & Koop and Poirier (1995) & 86 countries & $1960-1981$ & Panel data & $\begin{array}{l}\text { Cointegration, Granger } \\
\text { Causality }\end{array}$ & $\begin{array}{l}\text { Mixed } \\
\text { results }\end{array}$ \\
\hline
\end{tabular}




\begin{tabular}{|c|c|c|c|c|c|c|}
\hline 34 & $\begin{array}{l}\text { Hondroyiannis and } \\
\text { Papapetrou (1995) }\end{array}$ & Greece & 1951-1992 & Time series & $\begin{array}{l}\text { Cointegration, Granger } \\
\text { Causality }\end{array}$ & No support \\
\hline 35 & Nomura (1995) & Japan & 1960-1991 & Time series & Ordinary Least Squares & Support \\
\hline 36 & $\operatorname{Lin}(1995)$ & Mexico & $\begin{array}{c}1950- \\
1980,1950- \\
1990\end{array}$ & Time series & $\begin{array}{l}\text { Cointegration, Granger } \\
\text { Causality }\end{array}$ & Support \\
\hline 37 & Dao (1995) & 55 countries & 1980-1991 & Panel data & Ordinary Least Squares & $\begin{array}{l}\text { Mixed } \\
\text { results }\end{array}$ \\
\hline 38 & Bairam (1995) & U.S.A. & 1972-1991 & Time series & Ordinary Least Squares & $\begin{array}{l}\text { Mixed } \\
\text { results }\end{array}$ \\
\hline 39 & Payne and Ewing (1996) & 22 countries & 1948-1994 & Time series & $\begin{array}{l}\text { Cointegration, Granger } \\
\text { Causality }\end{array}$ & $\begin{array}{l}\text { Mixed } \\
\text { results }\end{array}$ \\
\hline 40 & Bohl (1996) & G7 countries & 1850-1995 & Time series & $\begin{array}{l}\text { Cointegration, Granger } \\
\text { Causality }\end{array}$ & $\begin{array}{l}\text { Mixed } \\
\text { results }\end{array}$ \\
\hline 41 & Ferris and West (1996) & U.S.A. & 1959-1989 & Time series & Ordinary Least Squares & No support \\
\hline 42 & $\begin{array}{l}\text { Afxentiou and Serletis } \\
\text { (1996) }\end{array}$ & $\begin{array}{l}6 \text { European } \\
\text { countries }\end{array}$ & 1961-1991 & Time series & $\begin{array}{l}\text { Ordinary Least Squares, } \\
\text { Granger causality }\end{array}$ & No support \\
\hline 43 & Ahsan et al. (1996) & Canada & 1952-1988 & Time series & $\begin{array}{l}\text { Cointegration, Granger } \\
\text { Causality }\end{array}$ & Support \\
\hline 44 & $\begin{array}{l}\text { Abdel-Rahman and Barry } \\
\text { (1997) }\end{array}$ & KSA countries & 1970-1991 & Time series & $\begin{array}{l}\text { Cointegration, Granger } \\
\text { Causality }\end{array}$ & $\begin{array}{l}\text { Mixed } \\
\text { results }\end{array}$ \\
\hline 45 & $\begin{array}{l}\text { Chletsos and Kollias } \\
\text { (1997) }\end{array}$ & Greece & 1958-1993 & Time series & $\begin{array}{l}\text { Cointegration, Granger } \\
\text { Causality }\end{array}$ & $\begin{array}{l}\text { Mixed } \\
\text { results }\end{array}$ \\
\hline 46 & Ansari et al. (1997) & 3 African countries & 1963-1990 & Time series & $\begin{array}{l}\text { Cointegration, Granger } \\
\text { Causality }\end{array}$ & $\begin{array}{l}\text { Mixed } \\
\text { results }\end{array}$ \\
\hline 47 & Sinha (1998) & Malaysia & 1950-1992 & Time series & $\begin{array}{l}\text { Cointegration, Granger } \\
\text { Causality }\end{array}$ & $\begin{array}{l}\text { Mixed } \\
\text { results }\end{array}$ \\
\hline 48 & $\begin{array}{l}\text { Abizadeh and Yousefi } \\
\text { (1998) }\end{array}$ & South Korea & 1960-1990 & Time series & Ordinary Least Squares & Support \\
\hline 49 & Karaggianni et al. (1998) & $\begin{array}{l}\text { European Union } \\
\text { countries }\end{array}$ & 1949-1998 & Time series & $\begin{array}{l}\text { Cointegration, Granger } \\
\text { Causality }\end{array}$ & $\begin{array}{l}\text { Mixed } \\
\text { results }\end{array}$ \\
\hline 50 & Thornton (1999) & 6 countries & $1850-1913$ & Time series & $\begin{array}{l}\text { Cointegration, Granger } \\
\text { Causality }\end{array}$ & Support \\
\hline 51 & Alleyne (1999) & $\begin{array}{l}4 \text { Caribbean } \\
\text { countries }\end{array}$ & 1950-1997 & Time series & $\begin{array}{l}\text { Cointegration, Granger } \\
\text { Causality }\end{array}$ & No support \\
\hline 52 & Biswal et al. (1999) & Canada & 1950-1995 & Time series & $\begin{array}{l}\text { Cointegration, Granger } \\
\text { Causality }\end{array}$ & $\begin{array}{l}\text { Mixed } \\
\text { results }\end{array}$ \\
\hline 53 & Asseery et al. (1999) & Iraq & $1950-1980$ & Time series & $\begin{array}{l}\text { Cointegration, Granger } \\
\text { Causality }\end{array}$ & $\begin{array}{l}\text { Mixed } \\
\text { results }\end{array}$ \\
\hline 54 & Demirbas (1999) & Turkey & 1950-1990 & Time series & $\begin{array}{l}\text { Cointegration, Granger } \\
\text { Causality }\end{array}$ & No support \\
\hline 55 & Agorastos et al. (1998) & Greece & 1980-1995 & Panel data & Cointegration & Support \\
\hline 56 & Kolluri et al. (2000) & G7 countries & 1960-1993 & Time series & $\begin{array}{l}\text { Cointegration, Granger } \\
\text { Causality }\end{array}$ & Support \\
\hline 57 & Islam (2001) & U.S.A. & 1929-1996 & Time series & $\begin{array}{l}\text { Cointegration, Granger } \\
\text { Causality }\end{array}$ & Support \\
\hline 58 & Al-Faris (2002) & $\begin{array}{l}\text { Gulf cooperation } \\
\text { council }\end{array}$ & 1970-1999 & Time series & $\begin{array}{l}\text { Cointegration, Granger } \\
\text { Causality }\end{array}$ & Support \\
\hline 59 & Albatel (2002) & South Arabia & 1964-1995 & Time series & $\begin{array}{l}\text { Cointegration, Granger } \\
\text { Causality }\end{array}$ & Support \\
\hline 60 & Chang (2002) & 6 countries & 1951-1996 & Time series & $\begin{array}{l}\text { Cointegration, Granger } \\
\text { Causality }\end{array}$ & $\begin{array}{l}\text { Mixed } \\
\text { results }\end{array}$ \\
\hline 61 & $\begin{array}{l}\text { Dar and Amirkhalkali } \\
(2002)\end{array}$ & OECD countries & 1971-1999 & Panel data & $\begin{array}{l}\text { Generalized Least } \\
\text { Squares }\end{array}$ & $\begin{array}{l}\text { Mixed } \\
\text { results }\end{array}$ \\
\hline 62 & Chow et al. (2002) & U.K. & 1948-1997 & Time series & $\begin{array}{l}\text { Cointegration, Granger } \\
\text { Causality }\end{array}$ & Support \\
\hline 63 & Legrenzi and Milas (2002) & Italy & 1959-1996 & Time series & $\begin{array}{l}\text { Cointegration, Granger } \\
\text { Causality }\end{array}$ & No support \\
\hline 64 & Burney (2002) & Kuwait & 1969-1994 & Time series & $\begin{array}{l}\text { Cointegration, Granger } \\
\text { Causality }\end{array}$ & No support \\
\hline 65 & Peters (2002) & 4 countries & 1948-1995 & Time series & Cointegration & $\begin{array}{l}\text { Mixed } \\
\text { results }\end{array}$ \\
\hline 66 & $\begin{array}{l}\text { Bagdigen and Cetintas } \\
\text { (2003) }\end{array}$ & Turkey & $1965-2000$ & Time series & $\begin{array}{l}\text { Cointegration, Granger } \\
\text { Causality }\end{array}$ & No support \\
\hline 67 & Haliciouglu (2003) & Turkey & $1960-2000$ & Time series & $\begin{array}{l}\text { Cointegration, Granger } \\
\text { Causality }\end{array}$ & No support \\
\hline 68 & Florio and Colautti (2005) & 5 countries & $1870-2000$ & Time series & Ordinary Least Squares & No support \\
\hline 69 & Al-Obaid (2004) & Saudi Arabia & $1970-2001$ & Time series & $\begin{array}{l}\text { Cointegration, Granger } \\
\text { Causality }\end{array}$ & Support \\
\hline
\end{tabular}

5 P a g e 


\begin{tabular}{|c|c|c|c|c|c|c|}
\hline 70 & Chang et al. (2004) & 10 countries & 1951-1996 & Time series & $\begin{array}{l}\text { Cointegration, Granger } \\
\text { Causality }\end{array}$ & $\begin{array}{l}\text { Mixed } \\
\text { results }\end{array}$ \\
\hline 71 & $\begin{array}{l}\text { Dritsakis and } \\
\text { Adamopoulos (2004) }\end{array}$ & Greece & 1960-2001 & Time series & $\begin{array}{l}\text { Cointegration, Granger } \\
\text { Causality }\end{array}$ & Support \\
\hline 72 & Wahab (2004) & OECD countries & $1950-2000$ & Panel data & $\begin{array}{l}\text { Cointegration, Granger } \\
\text { Causality }\end{array}$ & $\begin{array}{l}\text { Mixed } \\
\text { results }\end{array}$ \\
\hline 73 & Iyare and Lorde (2004) & 9 countries & $1950-2000$ & Time series & $\begin{array}{l}\text { Cointegration, Granger } \\
\text { Causality }\end{array}$ & $\begin{array}{l}\text { Mixed } \\
\text { results }\end{array}$ \\
\hline 74 & Dilrukshini (2004) & Sri Lanca & 1952-2002 & Time series & $\begin{array}{l}\text { Cointegration, Granger } \\
\text { Causality }\end{array}$ & No support \\
\hline 75 & Al Hasoon (2005) & $\begin{array}{l}\text { Gulf cooperation } \\
\text { council }\end{array}$ & 1975-2002 & Time series & $\begin{array}{l}\text { Cointegration, Granger } \\
\text { Causality }\end{array}$ & $\begin{array}{l}\text { Mixed } \\
\text { results }\end{array}$ \\
\hline 76 & Liu et al. (2005) & China & 1979-2002 & Time series & $\begin{array}{l}\text { Cointegration, Granger } \\
\text { Causality }\end{array}$ & No support \\
\hline 77 & Ahmad and Ahmed (2005) & D-8 Countries & 1973-2002 & Time series & $\begin{array}{l}\text { Cointegration, Granger } \\
\text { Causality }\end{array}$ & $\begin{array}{l}\text { Mixed } \\
\text { results }\end{array}$ \\
\hline 78 & Yuk (2005) & U.K. & 1830-1993 & Time series & $\begin{array}{l}\text { Cointegration, Granger } \\
\text { Causality }\end{array}$ & $\begin{array}{l}\text { Mixed } \\
\text { results }\end{array}$ \\
\hline 79 & $\begin{array}{l}\text { Loizides and Vamvoukas } \\
\text { (2005) }\end{array}$ & $\begin{array}{l}\text { Greece, U.K. and } \\
\text { Ireland }\end{array}$ & 1960-1995 & Time series & $\begin{array}{l}\text { Cointegration, Granger } \\
\text { Causality }\end{array}$ & $\begin{array}{l}\text { Mixed } \\
\text { results }\end{array}$ \\
\hline 80 & Dogan and Tang (2006) & $\begin{array}{l}\text { Five South East } \\
\text { Asian Countries }\end{array}$ & 1960-2002 & Time series & $\begin{array}{l}\text { Cointegration, Granger } \\
\text { Causality }\end{array}$ & No support \\
\hline 81 & Ju Huang (2006) & China and Taiwan & 1979-2002 & Time series & $\begin{array}{l}\text { Cointegration, Granger } \\
\text { Causality }\end{array}$ & No support \\
\hline 82 & Akitoby et al. (2006) & 51 countries & 1970-2002 & Time series & $\begin{array}{l}\text { Ordinary Least Squares, } \\
\text { Cointegration }\end{array}$ & $\begin{array}{l}\text { Mixed } \\
\text { results }\end{array}$ \\
\hline 83 & Sideris (2007) & Greece & 1833-1938 & Time series & $\begin{array}{l}\text { Cointegration, Granger } \\
\text { Causality }\end{array}$ & Support \\
\hline 84 & $\begin{array}{l}\text { Guerrero and Parker } \\
(2007)\end{array}$ & U.S.A. & $1792-2004$ & Time series & $\begin{array}{l}\text { Cointegration, Granger } \\
\text { Causality }\end{array}$ & Support \\
\hline 85 & Shelton (2007) & 100 countries & $1970-2000$ & Panel data & Ordinary Least Squares & $\begin{array}{l}\text { Mixed } \\
\text { results }\end{array}$ \\
\hline 86 & Rehman et al. (2007) & Pakistan & $1972-2004$ & Time series & Cointegration & Support \\
\hline 87 & Kolluri and Wahab (2007) & $\begin{array}{l}\text { OECD and EU } \\
\text { countries }\end{array}$ & $1950-2000$ & Panel data & Ordinary Least Squares & $\begin{array}{l}\text { Mixed } \\
\text { results }\end{array}$ \\
\hline 88 & Arpaia and Turrini (2008) & $\begin{array}{l}\text { European and } \\
\text { Monetary Union } \\
\text { countries }\end{array}$ & 1970-2003 & Panel data & Cointegration & Support \\
\hline 89 & Liu et al. (2008) & U.S.A. & 1947-2002 & Time series & $\begin{array}{l}\text { Ordinary Least Squares, } \\
\text { Granger causality }\end{array}$ & No support \\
\hline 90 & Narayan et al. (2008) & China & $1952-2003$ & Panel data & $\begin{array}{l}\text { Cointegration, Granger } \\
\text { Causality }\end{array}$ & $\begin{array}{l}\text { Mixed } \\
\text { results }\end{array}$ \\
\hline 91 & $\begin{array}{l}\text { Lamartina and Zaghini } \\
\text { (2008) }\end{array}$ & 23 OECD countries & $1970-2004$ & Panel data & Cointegration & Support \\
\hline 92 & Ghartey (2008) & Jamaica & 1960-2005 & Time series & $\begin{array}{l}\text { Cointegration, Granger } \\
\text { Causality }\end{array}$ & Support \\
\hline 93 & Narayan et al. (2008) & Fiji Islands & 1970-2002 & Time series & $\begin{array}{l}\text { OLS, Cointegration, } \\
\text { Granger causality }\end{array}$ & Support \\
\hline 94 & Samudran et al. (2009) & Malaysia & $1970-2004$ & Time series & Cointegration & Support \\
\hline 95 & Kumar et al. (2009) & New Zealand & 1960-2007 & Time series & $\begin{array}{l}\text { Ordinary Least Squares, } \\
\text { Cointegration }\end{array}$ & Support \\
\hline 96 & $\begin{array}{l}\text { Abul Kalam and Aziz } \\
\text { (2009) }\end{array}$ & Bagladesh & 1976-2009 & Time series & $\begin{array}{l}\text { Cointegration, Granger } \\
\text { Causality }\end{array}$ & Support \\
\hline 97 & Cavusoglou (2005) & Turkey & $\begin{array}{l}1923-2003, \\
1950-2003\end{array}$ & Time series & Cointegration & No support \\
\hline 98 & Babatube (2008) & Nigeria & 1970-2006 & Time series & $\begin{array}{l}\text { Cointegration, Granger } \\
\text { Causality }\end{array}$ & No support \\
\hline 99 & $\begin{array}{l}\text { Karaggianni and } \\
\text { Pempetzoglou (2009) }\end{array}$ & $\begin{array}{l}\text { European Union } \\
\text { countries }\end{array}$ & 1949-1998 & Time series & Granger Causality & $\begin{array}{l}\text { Mixed } \\
\text { results }\end{array}$ \\
\hline 100 & Yay and Tastan (2009) & Turkey & 1950-2004 & Time series & $\begin{array}{l}\text { Cointegration, Granger } \\
\text { Causality }\end{array}$ & Support \\
\hline 101 & Tang (2010) & Malaysia & $1960-2005$ & Time series & $\begin{array}{l}\text { Cointegration, Granger } \\
\text { Causality }\end{array}$ & Support \\
\hline 102 & $\begin{array}{l}\text { Katrakilidis and Tsaliki } \\
\text { (2009) }\end{array}$ & Greece & 1958-2004 & Time series & Cointegration & Support \\
\hline 103 & Dolenc (2009) & Slovenia & 1992-2007 & Time series & Ordinary Least Squares & $\begin{array}{l}\text { Mixed } \\
\text { results }\end{array}$ \\
\hline 104 & $\begin{array}{l}\text { Maggazino } \\
\text { (2010b) }\end{array}$ & Italy & 1960-2004 & Time series & $\begin{array}{l}\text { Cointegration, Granger } \\
\text { Causality }\end{array}$ & Support \\
\hline
\end{tabular}

6| P a g e 


\begin{tabular}{|c|c|c|c|c|c|c|}
\hline 105 & $\begin{array}{l}\text { Maggazino } \\
\text { (2010a) }\end{array}$ & $\begin{array}{l}\text { European Union } \\
\text { countries }\end{array}$ & 1970-2009 & Panel data & $\begin{array}{l}\text { Cointegration, Granger } \\
\text { Causality }\end{array}$ & $\begin{array}{l}\text { Mixed } \\
\text { results }\end{array}$ \\
\hline 106 & Zheng et al. (2010) & China & 1952-2007 & Time series & Ordinary Least Squares & No support \\
\hline 107 & Verma and Arora (2010) & India & $1950-2008$ & Time series & Cointegration & Support \\
\hline 108 & Afzal and Abbas (2010) & Pakistan & $1960-2007$ & Time series & $\begin{array}{l}\text { Cointegration, Granger } \\
\text { Causality }\end{array}$ & No support \\
\hline 109 & Iniguez-Montiel (2010) & Mexico & 1950-1999 & Time series & $\begin{array}{l}\text { Cointegration, Granger } \\
\text { Causality }\end{array}$ & Support \\
\hline 110 & $\begin{array}{l}\text { Abdullah and Maamor } \\
\text { (2010) }\end{array}$ & Malaysia & 1970-2007 & Time series & Cointegration & $\begin{array}{l}\text { Mixed } \\
\text { results }\end{array}$ \\
\hline 111 & $\begin{array}{l}\text { Ighorado and Oriakhi } \\
\text { (2010) }\end{array}$ & Nigeria & 1961-2007 & Time series & $\begin{array}{l}\text { Cointegration, Granger } \\
\text { Causality }\end{array}$ & No support \\
\hline 112 & Pahlavani et al. (2011) & Iran & $1960-2008$ & Time series & $\begin{array}{l}\text { Cointegration, Granger } \\
\text { Causality }\end{array}$ & Support \\
\hline 113 & Oteng-Abayie (2011) & $\begin{array}{l}5 \text { Sub-Saharan } \\
\text { countries }\end{array}$ & 1986-2004 & Panel data & Cointegration & No support \\
\hline 114 & $\begin{array}{l}\text { Priesmeier and Koester } \\
\text { (2012) }\end{array}$ & Germany & $1960-2007$ & Time series & Cointegration, ECM & Support \\
\hline 115 & Kesavarajah (2012) & Sri Lanka & $1960-2010$ & Time series & $\begin{array}{l}\text { Cointegration, Granger } \\
\text { Causality }\end{array}$ & No support \\
\hline 116 & Ageli (2013) & Saudi Arabia & $1970-2012$ & Time series & Cointegration, ECM & Support \\
\hline 117 & Mutuku and Kimani(2012) & Kenya & 1960-2009 & Time series & $\begin{array}{l}\text { Cointegration, Granger } \\
\text { Causality }\end{array}$ & Support \\
\hline 118 & $\begin{array}{l}\text { Menyah and Wolde- } \\
\text { Rufael (2012) }\end{array}$ & South Africa & 1950-2007 & Time series & OLS & Support \\
\hline 119 & $\begin{array}{l}\text { Richter and Paparas } \\
\text { (2012) }\end{array}$ & United Kingdom & $1850-2010$ & Time series & $\begin{array}{l}\text { Cointegration, Granger } \\
\text { Causality }\end{array}$ & Support \\
\hline 120 & Njimanted (2012) & Cameroon & $1980-2012$ & Time series & Cointegration & No support \\
\hline 121 & Permana and Wika (2013) & Indonesia & 1999-2011 & Time series & ARDL, GARCH & Support \\
\hline 122 & Antoniou et al. (2013) & Greece & 1833-1938 & Time series & ARDL & Support \\
\hline 123 & Alimi (2012) & Nigeria & $1970-2012$ & Time series & Cointegration, ECM & Support \\
\hline 124 & $\begin{array}{l}\text { Bashirli and Sabiroglu } \\
\text { (2013) }\end{array}$ & Azerbaijan & 2001-2010 & Time series & Bounds testing, ARDL & Support \\
\hline 125 & $\begin{array}{l}\text { Richter and Paparas } \\
\text { (2013a) }\end{array}$ & Greece & $1883-2010$ & Time series & $\begin{array}{l}\text { Cointegration, Granger } \\
\text { Causality }\end{array}$ & Support \\
\hline 126 & $\begin{array}{l}\text { Grenade and Wright } \\
(2014)\end{array}$ & $\begin{array}{l}\text { Selected } \\
\text { Caribbean } \\
\text { countries }\end{array}$ & 1980-2011 & Panel data & $\begin{array}{l}\text { OLS, Granger causality } \\
\text { tests }\end{array}$ & No support \\
\hline
\end{tabular}

The majority of studies examined the validity of Wagner's law published during the last 20 years. Interest for the Wagner hypothesis attracted the attention of many economists after the translation of the original work of Wagner by Cooke (1958), however the interest had declined at the end of 1970s. Although, the increased public spending in most countries, new development of econometric techniques, and the last translation of Wagner's work by Biehl (1998) attracted again the interest of many policy makers and economists.

\section{Type of Analysis}

There are two types of analysis used to examine Wagner's law validity, time series and panel data analysis. Studies using time series analysis examine the effect of the national income growth on the expansion of government expenditures over time for a particular country. The panel data analysis investigates the relationship between national income and government expenditures across different countries. Bird (1971) implied that studies using panel data in order to examine the validity of 
Wagner's law are irrelevant, since a postulated change in the public sector happens over time. Henrekson (1993) used long-term data for the Swedish economy and claimed that the growth of public sector is a process occurring over time in a single country.

On the other hand, Michas (1975) argued that panel data analysis is more relevant because there is an examination of a number of countries and the law can be generalized. Gupta (1967) commented on the Peacock-Wiseman displacement effect hypothesis that they tested only the case of the United Kingdom, however, before making any generalizations they should also test the case of other countries. Wahab (2004) claimed that by including panel data analysis in his study he maximized sample size and increased the power of empirical tests. Ram (1987) suggested that most authors examining developing countries prefer panel data analysis since long-time series for these countries are unavailable. However, studies using panel data analysis in order to test developing countries and find evidence of positive relationship between national income and spending, does not necessarily mean that this country will have increased growth over time.

During the last decade many databases were created by the International Monetary Fund (IMF), European commission, OECD, International Financial Statistics (IFS), Penn World Tables (PWT). Slemrond (1995) stated that "the recent availability of a great quantity of comparable cross-country data, due to the work of Robert Summers and Allan Heston, stimulated revival of empirical studies on issues such as the determinants of growth." (Slemrod 1995, pp. 395). According to our review of the literature in this topic, the majority of previous studies have applied time series analysis. We can see in Table 2 that 106 out of 126 studies used time series analysis and accounted for almost $84.1 \%$ of the total studies. The studies that deployed panel data analysis are accounted for only $15.9 \%$. Finally, there are 3 studies using both of the analyses in order to examine the validity of Wagner's law $(2.4 \%)$.

Table 2: Type of analysis used from previous studies

\begin{tabular}{lc}
\hline Type of analysis & $\begin{array}{c}\text { Number of } \\
\text { studies }\end{array}$ \\
\hline Panel data & 20 \\
\hline Time series & 106 \\
Total number of studies & 126 \\
\hline
\end{tabular}

\section{Time series analysis}

In this paper we identified that 106 out of the 126 empirical studies in the literature applied time series analysis in order to examine the validity of Wagner's law. A large proportion of these studies have tested the law for a single country, while only a few have examined a group of countries. In addition, while some of the studies using time series data examined developing countries, most have focused on developed and industrialized countries.

\section{Panel data analysis}

This type of analysis is applied to test a group of countries or to examine states or regions. Noticeably, this analysis covers a much wider range of countries in contrast to time series analysis. While time series analysis is mostly used in developing countries, this type of analysis is used mostly in groups of developing countries. In the introduction of this section we mention that the reason why this occurs is the unavailability of long data series or developing countries. There are several studies used panel data analysis in order to examine the case of group of countries or the states of a country.

\section{Type of analysis and Empirical results}


Among the 106 studies applied time series data, the majority of the studies (47\%) found support of the validity of Wagner's law. The $30 \%$ of time series studies found that the law is invalid, while the mixed results accounted for about $23 \%$ and was the less frequent result. Among the studies applied Panel data analysis (20), the $50 \%$ of them had mixed results (across different countries or across different versions), $30 \%$ found support of the law and $20 \%$ found that the law is invalid. (Table 3 ).

Table 3: Type of analysis and empirical results

\begin{tabular}{lccc}
\hline Row Labels & Panel data & $\begin{array}{c}\text { Time } \\
\text { series }\end{array}$ & $\begin{array}{c}\text { Grand } \\
\text { Total }\end{array}$ \\
\hline Mixed results & 10 & 25 & 35 \\
No support & 4 & 31 & 35 \\
Support & 6 & 50 & 56 \\
Grand Total & $\mathbf{2 0}$ & $\mathbf{1 0 6}$ & $\mathbf{1 2 6}$ \\
\hline
\end{tabular}

States

In our revision of the existing literature that examined Wagner's law, three studies (Table 4) focused on the states or regions of a country by using panel data analysis and one using time series analysis. Yousefi and Abizadeh (1992) and Agorastos et al. (1998) supported Wagner's hypothesis, while Narayan et al. (2008) found mixed results. Narayan et al. (2008) presented also the advantages of a study that focuses on states.

Table 4: Studies that examined the Wagner's Law by focusing on states or regions

\begin{tabular}{cllcll}
\hline No & Author & Country & Time period & Type of Analysis & Main results \\
\hline $\mathbf{1}$ & $\begin{array}{l}\text { Yousefi and } \\
\text { Abizadeh (1992) }\end{array}$ & U.S.A. & 1950-1985 & Time series & Support \\
$\mathbf{2}$ & $\begin{array}{l}\text { Agorastos et al. } \\
(1998)\end{array}$ & Greece & $1980-1995$ & Panel data & Support \\
$\mathbf{3}$ & $\begin{array}{l}\text { Narayan et al. } \\
(2008)\end{array}$ & China & $1952-2003$ & Panel data & Mixed results \\
\hline
\end{tabular}

\section{Time span}

The majority of previous studies used post World-War II data and tested periods less than 50 years. However there are several studies (Table 5) that examine long data sets for single countries or group of countries. One of the most important assumptions of original Wagner's hypothesis is that the tested country has to be in early stages of development, urbanisation and modernization. Hence, Wagner's law might be more applicable to newly industrialized and developing countries or developed countries by using data for the period between late $19^{\text {th }}$ century and World War II. During this period we expect to find support of the law in most of the countries, since they transformed their economies from rural agricultural to urban industrial with increased demand for public services (infrastructure). However, focusing on empirical results of studies that used long series we realise that results are mixed and do not follow any common pattern.

Furthermore, one might expect that any examination of the validity of Wagner's hypothesis in a developed country for the period after the World War II will lead to results indicate no support of the law. This is because most of the developed countries would have less demand for public services, since there is a weak relationship between government spending and national income in high levels of 
development and industrialisation. However, many studies on countries such as the U.K (Chow et al. 2002, U.S.A (Islam 2001) and other developed European Union countries (Maggazino 2010a) show supportive evidence of the validity of the law for the period after World War II.

Table 5: Studies examined Wagner's Law by using long data series

\begin{tabular}{|c|c|c|c|c|c|}
\hline No & Author & Country & Time period & Type of Analysis & Main results \\
\hline 1 & Henrekson (1993) & Sweden & $1861-1990$ & Time series & No support \\
\hline 2 & Oxley (1994) & Britain & $1870-1913$ & Time series & Support \\
\hline 3 & Bohl(1996) & G7 countries & 1850-1995 & Time series & Mixed results \\
\hline 4 & Thornton (1999) & 6 countries & $1850-1913$ & Time series & Support \\
\hline 5 & $\begin{array}{l}\text { Florio and Colautti } \\
\text { (2005) }\end{array}$ & 5 countries & $1870-2000$ & Time series & No support \\
\hline 6 & Yuk(2005) & U.K. & $1830-1993$ & Time series & Mixed results \\
\hline 7 & Sideris (2007) & Greece & $1833-1938$ & Time series & Support \\
\hline 8 & $\begin{array}{l}\text { Guerrero and } \\
\text { Parker (2007) }\end{array}$ & U.S.A. & $1792-2004$ & Time series & Support \\
\hline 9 & Cavusoglou(2005) & Turkey & $\begin{array}{l}\text { 1923-2003, 1950- } \\
2003\end{array}$ & Time series & No support \\
\hline 10 & $\begin{array}{l}\text { Richter and } \\
\quad \text { Paparas (2012) }\end{array}$ & U.K. & $1850-2010$ & Time series & Support \\
\hline 11 & $\begin{array}{l}\text { Antoniou et al. } \\
\text { (2012) }\end{array}$ & Greece & $1833-1938$ & Time series & Support \\
\hline 12 & $\begin{array}{r}\text { Richter and } \\
\text { Paparas } \\
(2013 a)\end{array}$ & Greece & $1883-2010$ & Time series & Support \\
\hline
\end{tabular}

Studies examined the validity of the law by using long data sets used only time series analysis, the majority of them (58\%) found support of the law , $25 \%$ found that the law is invalid and finally $17 \%$ of these studies had mixed results. We discussed in the previous section why the use of long data sets examining the law is more appropriate (Table 6).

Table 6

\begin{tabular}{|c|c|c|c|c|c|}
\hline Row Labels & Mixed results & & $\begin{array}{l}\text { No } \\
\text { support }\end{array}$ & Support & $\begin{array}{l}\text { Grand } \\
\text { Total }\end{array}$ \\
\hline Time series & & 2 & 3 & 7 & 12 \\
\hline Grand Total & & 2 & 3 & 7 & 12 \\
\hline
\end{tabular}

\section{Methods}

Among a large number of studies (Table 7) that examined Wagner's law for various countries, there have been used many methods of analysis. The most important of them are the following: ordinary least squares for stochastic modelling, cointegration approach for examining if there is any long run relationship between spending and national income and finally Granger causality tests for identifying the direction of the causality. The majority of the studies used recent econometric techniques such as cointegration analysis and Granger causality tests, while studies before 1985 mostly used Ordinary least squares method.

Table 7: Methods used to examine Wagner's Law

\begin{tabular}{ll}
\hline Method & Studies \\
\hline
\end{tabular}




\begin{tabular}{lr}
\hline Cointegration & 18 \\
\hline Cointegration, Granger Causality & 63 \\
\hline Generalized Least Squares & 1 \\
\hline Granger Causality & 1 \\
\hline OLS, Cointegration, Granger causality & 1 \\
\hline Ordinary Least Squares & 36 \\
\hline Ordinary Least Squares, Cointegration & 2 \\
\hline Ordinary Least Squares, Granger causality & 4 \\
\hline Total & $\mathbf{1 2 6}$ \\
\hline
\end{tabular}

\section{OLS}

Studies applied OLS mainly ignored the problems of spurious regression and their empirical results are based on non-stationary time series. On the other side, cointegration analysis overcomes this problem by examining the long run relationship between the tested variables and estimating the short run dynamics by an error correction model. When they find evidence of long run relationship they use Granger causality test to identify the direction of causality. Henrekson (1993) implied that studies used time series analysis and supported the validity of Wagner's law are likely to suffer from spurious regression, since they used OLS on non-stationary series. Courakis et al. (1993) made an assumption that the tested series are stationary and then applied the OLS, however their findings might be inaccurate.

\section{Cointegration techniques (Johansen, Engle-Granger, Bound test)}

The majority of the studies during the last decades used one of the cointegration approaches in order to examine the long run relationship between economic growth and government spending.In the past, some authors focused in the positive relationship between government spending and national income rather than on the direction of the causality. Peacock and Scott (2000) criticized previous studies testing Wagner's hypothesis empirically, state the consistency of the cointegration approach with Wagner's view. According to Peacock and Scott (2000) "Wagner does not present an articulated model of the growth process in which cause and effect are clearly delineated". pp.3.

Cavusoglou suggested that "However, the conventional cointegration techniques, such as EngleGranger (1987) and Johansen (1988 and 1992) approaches, require the underlying time series data to be integrated of order one. The bounds testing approach outperforms the conventional techniques when there is the uncertainty of mixed order of integration resulting from the lack of power of unit root tests". pp.75.

\section{Granger causality test}

Finally, there are studies that used Granger causality tests in the short run dynamics error correction model and try to identify the direction of the causality between government spending and national income. In order to apply this test they have to establish an existence of a cointegrating vector. We have to mention that most recent studies apply Granger causality tests and the majority of them support or not support the law, there are only very few studies applied Granger tests and found mixed results.

\section{Methodology and Empirical results}


In table 8 we can see the relationship between the methodology applied to examine the validity of the law and the empirical results. Most of the studies before 1990s used OLS, while after 1990 the majority of the studies applied cointegration techniques and granger causality tests.

Table 8: Methodology and empirical results

\begin{tabular}{lrrrr}
\hline Row Labels & Mixed results & \multicolumn{2}{c}{$\begin{array}{l}\text { No } \\
\text { support }\end{array}$} & $\begin{array}{c}\text { Support } \\
\text { Grand } \\
\text { Total }\end{array}$ \\
\hline Cointegration & 2 & 3 & 13 & 18 \\
Cointegration, Granger Causality & 20 & 18 & 25 & 63 \\
Generalized Least Squares & 1 & & & 1 \\
Granger Causality & 1 & & & 1 \\
OLS, Cointegration, Granger causality & & & 1 & 1 \\
Ordinary Least Squares & 10 & 11 & 15 & 36 \\
Ordinary Least Squares, Cointegration & 1 & & 1 & 2 \\
$\begin{array}{l}\text { Ordinary Least Squares, Granger } \\
\text { causality }\end{array}$ & & 3 & 1 & 4 \\
Grand Total & $\mathbf{3 5}$ & $\mathbf{3 5}$ & $\mathbf{5 6}$ & $\mathbf{1 2 6}$ \\
\hline
\end{tabular}

\section{Methodology and Type of analysis}

In table 9 we can see that the majority of studies used times series data, applied cointegration and granger causality analysis and accounted for about $69 \%$. On the other side, $45 \%$ of studies applied panel data analysis included the OLS.

Table 9: Methodology and type of analysis

\begin{tabular}{lrrr}
\hline Row Labels & Panel data & \multicolumn{1}{c}{$\begin{array}{l}\text { Time } \\
\text { series }\end{array}$} & \multicolumn{2}{c}{$\begin{array}{l}\text { Grand } \\
\text { Total }\end{array}$} \\
\hline Cointegration & 4 & 14 & 18 \\
Cointegration, Granger Causality & 4 & 59 & 63 \\
Generalized Least Squares & 1 & & 1 \\
Granger Causality & & 1 & 1 \\
OLS, Cointegration, Granger causality & & 1 & 1 \\
Ordinary Least Squares & 9 & 27 & 36 \\
Ordinary Least Squares, Cointegration & & 2 & 2 \\
Ordinary Least Squares, Granger & 2 & 2 & 4 \\
causality & & & $\mathbf{1 2 6}$ \\
\hline Grand Total & $\mathbf{2 0}$ & $\mathbf{1 0 6}$ & \\
\hline
\end{tabular}

\section{Results}

There is a large volume of literature examined the validity of Wagner's law but there is no clear pattern on the empirical results (Table 10). There is a group of studies ${ }^{3}$ that found supportive evidence of the validity of the law and accounted for about $44.4 \%$. Their results suggest that there is a long run relationship between national income and public spending, furthermore there is causality runs from

\footnotetext{
${ }^{3}$ For instance: Gyles (1991), Oxley (1994), Kolluri et al. (2000), Islam(2001) and Dritsakis and Adamopoulos (2004).
} 
income to growth. There is another group of empirical studies ${ }^{4}$ found evidence that do not support Wagner's hypothesis, and they accounted for $27.8 \%$.

Table 10: Results of previous studies

\begin{tabular}{lr}
\hline Results & $\begin{array}{l}\text { Number of } \\
\text { studies }\end{array}$ \\
\hline Mixed results & 35 \\
No support & 35 \\
Support & 56 \\
Total & $\mathbf{1 2 6}$ \\
\hline
\end{tabular}

The basic implications of the absence of a long-run relationship between government activity and economic development in a country are firstly the possible weak association between public activity and economic growth. Maybe because of the crucial role of other factors, which according to Legrenzi and Milas (2002) "the role of omitted variables in identifying a long-run equilibrium relationship ... "pp.435. Another implication may be the application of inappropriate measures of government spending or economic growth.

\section{Mixed results}

There is another strand of the literature found mixed results (Table 11) in the relationship between spending and national income and accounted for $27.8 \%$ of all studies. These studies used data from different countries and found positive relationship for some of them and different results for other ones $^{5}$. Or they used different versions of the law for a specific country but some versions support the law and other has contradictory results ${ }^{6}$.

Table 11: Studies with mixed results about the validity of Wagner's Law

\begin{tabular}{|c|c|c|c|c|c|}
\hline 1 & Man (1980) & Mexico & 1913-1958 & Mixed results & 4 of 6 versions supportive \\
\hline 2 & $\begin{array}{l}\text { Abizabeh and Gray } \\
\text { (1985) }\end{array}$ & 55 countries & 1963-1976 & Mixed results & Mixed results across group of countries \\
\hline 3 & Afxentiou (1986) & Cyprus & 1960-1982 & Mixed results & 4 of 6 versions supportive \\
\hline 4 & Ram (1987) & 115 countries & $1950-1980$ & Mixed results & Mixed results across methodologies \\
\hline 5 & Bairam (1992) & OECD countries & 1950-1985 & Mixed results & Mixed results across countries \\
\hline 6 & Koop and Poirier(1995) & 86 countries & 1960-1981 & Mixed results & Mixed results across countries \\
\hline 7 & Dao (1995) & 55 countries & 1980-1991 & Mixed results & $\begin{array}{l}\text { Mixed results across different type of public } \\
\text { spending }\end{array}$ \\
\hline 8 & Bairam (1995) & U.S.A. & 1972-1991 & Mixed results & $\begin{array}{l}\text { Mixed results across different type of public } \\
\text { spending }\end{array}$ \\
\hline 9 & Payne and Ewing (1996) & 22 countries & 1948-1994 & Mixed results & Mixed results across countries \\
\hline 10 & Bohl(1996) & G7 countries & 1850-1995 & Mixed results & Mixed results across countries \\
\hline 11 & $\begin{array}{l}\text { Abdel-Rahman and Barry } \\
\text { (1997) }\end{array}$ & KSA countries & 1970-1991 & Mixed results & Mixed results across countries \\
\hline 12 & $\begin{array}{l}\text { Chletsos and Kollias } \\
(1997)\end{array}$ & Greece & 1958-1993 & Mixed results & $\begin{array}{l}\text { Mixed results across different type of public } \\
\text { spending }\end{array}$ \\
\hline 13 & Ansari et al. (1997) & 3 African countries & 1963-1990 & Mixed results & Mixed results across countries \\
\hline 14 & Sinha(1998) & Malaysia & 1950-1992 & Mixed results & Cointegration supportive, Granger against \\
\hline
\end{tabular}

\footnotetext{
${ }^{4}$ Henrekson (1993), Courakis et al. (1993), Hondroyiiannis and Papapetrou (1995), Ferris and West (1996), Legrenzi and Milas (2002)and Burney (2002).

${ }^{5}$ Ram (1987), Bohl (1996), Ansari (1997), Karagianni (1998), Chang (2002) and Chang (2004).

${ }^{6}$ Man (1980), Chletsos (1997), Biswal (1999) and Asseery (1999).
} 


\begin{tabular}{|c|c|c|c|c|c|}
\hline 15 & Karaggianni et al. (1998) & $\begin{array}{l}\text { European Union } \\
\text { countries }\end{array}$ & 1949-1998 & Mixed results & Mixed results across countries \\
\hline 16 & Biswal et al. (1999) & Canada & 1950-1995 & Mixed results & $\begin{array}{l}\text { Mixed results across different type of public } \\
\text { spending }\end{array}$ \\
\hline 17 & Asseery et al. (1999) & Iraq & 1950-1980 & Mixed results & Constant prices supportive, real against \\
\hline 18 & Chang (2002) & 6 countries & 1951-1996 & Mixed results & Mixed results across countries \\
\hline 19 & $\begin{array}{l}\text { Dar and } \\
\text { Amirkhalkali(2002) }\end{array}$ & OECD countries & 1971-1999 & Mixed results & Mixed results across countries \\
\hline 20 & Peters (2002) & 4 countries & 1948-1995 & Mixed results & Engle mixed results, Johansen supportive \\
\hline 21 & Chang et al. (2004) & 10 countries & 1951-1996 & Mixed results & Mixed results across countries \\
\hline 22 & Wahab (2004) & OECD countries & $1950-2000$ & Mixed results & Mixed results across group of countries \\
\hline 23 & Iyare and Lorde (2004) & 9 countries & $1950-2000$ & Mixed results & $\begin{array}{l}\text { Mixed results across countries and across } \\
\text { versions }\end{array}$ \\
\hline 24 & $\begin{array}{l}\text { Ahmad and Ahmed } \\
\text { (2005) }\end{array}$ & D-8 Countries & 1973-2002 & Mixed results & Mixed results across methodologies \\
\hline 25 & Yuk(2005) & U.K. & 1830-1993 & Mixed results & Mixed results across different periods \\
\hline 26 & $\begin{array}{l}\text { Loizides and } \\
\text { Vamvoukas(2005) }\end{array}$ & Greece, U.K. and Ireland & 1960-1995 & Mixed results & Mixed results across countries \\
\hline 27 & Al Hasoon(2005) & Gulf cooperation council & $1975-2002$ & Mixed results & $\begin{array}{l}\text { Mixed results across countries and across } \\
\text { versions }\end{array}$ \\
\hline 28 & Akitoby et al.(2006) & 51 countries & $1970-2002$ & Mixed results & Mixed results across countries \\
\hline 29 & Shelton(2007) & 100 countries & $1970-2000$ & Mixed results & $\begin{array}{l}\text { Mixed results across different type of public } \\
\text { spending }\end{array}$ \\
\hline 30 & Kolluri and Wahab(2007) & OECD and EU countries & $1950-2000$ & Mixed results & Mixed results across group of countries \\
\hline 31 & Narayan et al. (2008) & China & $1952-2003$ & Mixed results & Mixed results across states \\
\hline 32 & $\begin{array}{l}\text { Karaggianni and } \\
\text { Pempetzoglou (2009) }\end{array}$ & $\begin{array}{l}\text { European Union } \\
\text { countries }\end{array}$ & 1949-1998 & Mixed results & Mixed results across countries \\
\hline 33 & Dolenc (2009) & Slovenia & 1992-2007 & Mixed results & 5 of 6 versions supportive \\
\hline 34 & Maggazino(2010b) & Italy & 1960-2004 & Mixed results & 3 of 5 versions supportive \\
\hline 35 & $\begin{array}{l}\text { Abdullah and Maamor } \\
(2010)\end{array}$ & Malaysia & 1970-2007 & Mixed results & 4 of 5 versions supportive \\
\hline
\end{tabular}

\section{Keynes vs. Wagner}

Finally, there are a number of studies (Table 12) that tested the Wagner's law against the Keynesian hypothesis. The Keynesian theoretical framework of economic growth suggests a long-run relationship between national income and government expenditures. However, this causal relationship runs from expenditures to income which is in contrast with Wagner's law. There are some studies such as Liu et al. (2008) Katrakilidis and Tsaliki (2009) Tang (2010) Samudran et al. (2009) that found evidence of bidirectional causality between national income and government spending, hence support for Wagner's and Keynesian hypothesis. There are also studies such as Afxentiou and Serletis (1996) and Demirbas(1999) that did not find any causal relationship between these variables and suggest that both hypotheses are invalid. Finally, is very important to mention here that if the Wagner's law is not valid for a country, does not necessarily mean that also the Keynesian hypothesis is invalid.

Table 12: Studies examined Keynesian hypothesis against Wagner's Law

\begin{tabular}{cllcc}
\hline No & Author & Country & $\begin{array}{c}\text { Main results } \\
\text { Wagner }\end{array}$ & $\begin{array}{c}\text { Main results } \\
\text { Keynes }\end{array}$ \\
\hline $\mathbf{1}$ & $\begin{array}{l}\text { Afxentiou and Serletis } \\
(1996)\end{array}$ & 6 European countries & No support & No support \\
$\mathbf{2}$ & Ansari et al. (1997) & 3 African countries & Mixed results & No support \\
$\mathbf{3}$ & Demirbas(1999) & Turkey & No support & No support \\
\hline
\end{tabular}

14 | $P$ a g e 


\begin{tabular}{|c|c|c|c|c|}
\hline 4 & Biswal et al. (1999) & Canada & Mixed results & Support \\
\hline 5 & Al-Faris (2002) & Gulf cooperation council & Support & No support \\
\hline 6 & Albatel (2002) & South Arabia & Support & Support \\
\hline 7 & $\begin{array}{l}\text { Bagdigen and } \\
\text { Cetintas(2003) }\end{array}$ & Turkey & No support & No support \\
\hline 8 & Dilrukshini(2004) & Sri Lanca & No support & No support \\
\hline 9 & $\begin{array}{l}\text { Dritsakis and } \\
\text { Adamopoulos (2004) }\end{array}$ & Greece & Support & Support \\
\hline 10 & Ju Huang (2006) & China and Taiwan & No support & No support \\
\hline 11 & Liu et al. (2008) & U.S.A. & No support & Support \\
\hline 12 & $\begin{array}{l}\text { Katrakilidis and Tsaliki } \\
\text { (2009) }\end{array}$ & Greece & Support & Support \\
\hline 13 & Tang (2010) & Malaysia & Support & Support \\
\hline 14 & Samudran et al. (2009) & Malaysia & Support & Support \\
\hline 15 & Maggazino(2010b) & Italy & Support & No support \\
\hline 16 & Maggazino(2010a) & European Union countries & Mixed results & No support \\
\hline 17 & Iniguez-Montiel (2010) & Mexico & Support & Support \\
\hline 18 & Pahlavani et al. (2011) & Iran & Support & No support \\
\hline
\end{tabular}

\section{Discussion}

During the last decades a large number of authors tested various specifications of Wagner's law. These studies used both time series and cross-sectional data sets and empirically examined the law for a single country and for a group of countries (multi-country studies). Moreover, there are studies using data on government expenditure at the provincial or state level. Existing studies in this topic vary in the country selection. They used data for developed, developing countries or group of both, while most of them examined developed or industrial countries. However, during the last 5 years there are an increased number of studies examining the case of developing countries from Africa and South Asia. Another strand of literature examined the Wagner's against Keynesian hypothesis. The empirical results across all these studies vary; some of them found support of the law, a number of studies found that the law is invalid, while a number of them found mixed results across different versions of the law or across different countries.

In this paper we try to provide a synthesis of previous empirical work in Wagner's law. We provide analysis of the year of publication, tested period, type of analysis, type of methodology and main conclusion for the validity of the law. Our findings are:

- Wagner's hypothesis has been the focus of many economists during the last century. However, the worldwide concern on the increased public spending in many countries and the developments on econometric techniques during the last 20 years attracted the interest of many policy makers and economists.

- The majority of previous studies have applied time series analysis; 106 out of 126 studies used time series analysis, while studies deployed panel data analysis are only 20. Among the studies which used time series analysis, the majority found support of the law. The majority of studies that deployed panel data analysis found mixed results. 
- There are several studies that used long data and used only time series analysis. Most of them (58\%) found support of the law.

- Among a large number of studies that examined Wagner's law for various countries, multiple methods of analysis have been used. The most important are the following: ordinary least squares for stochastic modelling, cointegration approach for examining if there is any long run relationship between spending and national income and finally Granger causality tests for identifying the direction of the causality. The majority of the studies used recent econometric techniques, such as cointegration analysis and Granger causality tests, while most studies before 1985 used Ordinary least squares method.

- The majority of studies that used times series data, applied cointegration and Granger causality analysis. On the other hand, most studies which implemented panel data analysis applied OLS.

- A large number of studies examined the validity of Wagner's law, but there is no clear pattern on the empirical results.

- Several studies tested Wagner's law against the Keynesian hypothesis. Some studies found support of both hypotheses, while others found that both are invalid.

- Studies that applied OLS ignored the problems of spurious regression and their empirical results are based on non-stationary time series and their findings might be inaccurate. On the other hand, cointegration analysis overcomes this problem by examining the long run relationship between the tested variables and estimating the short run dynamics by an error correction model. When they find evidence of long run relationship they use Granger causality test to identify the direction of causality. However, they do not take account any structural change in tested series and assume that there is no structural break.

\section{Conclusion}

As we have mentioned above, there are several studies that have an empirical support of both classical hypotheses: Wagner's law and Keynesian hypothesis, provides a further direction for analysing policy issues, and exposes a fundamental understanding to the government or policy makers about interlinkages between public expenditures and economic growth. The indication of this inter-dependency between these variables reproduce the effectiveness of government expenditure as fiscal instrument in stimulating economic growth, and the contribution of economic growth in government budget formulation. These results are by no means surprising. After all, all tests include a measure of GDP and government expenditure. As government expenditure is part of the GDP, we are actually estimating a sort of identity making it difficult to identify any causal relationship. Therefore, it is necessary to rethink the concept of using government expenditure. We suggest to include for future research welfare expenditure by the government. Although, it is true that welfare expenditure as part of government expenditure is also included in the overall GDP calculation, it does not necessarily move in line with GDP. For example, welfare expenditure could well fall or remain constant if GDP increases. The question is whether those data are available which therefore constitutes a new research project.

The first limitation of previous studies in the examination of the validity of Wagner's law is the difficulty of measuring the government activity only with fiscal measures. Wagner in his original study 
highlighted the twofold faces the government: the fiscal and the regulatory government. However, the regulatory government is included neither in our thesis nor in any other study in the past. The reason is that there is no measure which can be included into empirical modelling and take into account accurately the regulations of the government. Another limitation is that according to Wagner "all earlier attempts to lay down absolute figures of expenditure or to define an upper limit of its proportion to national income, have always miscarried" ((Cooke 1958, pp. 8)). Wagner in his original study recognised that the state expansion has some limits. He mentioned that the proportion between government spending and national income may not be permanently overstepped.

Nijkamp and Poot (2004) claimed that while the previous research on this subject has peaked in the late 1990s, additional publications will unquestionably appear and they are needed. Even among growth regression models, there are still numerous issues that require more attention. A noticeable issue is the endogeneity of government expenditure itself. The size of government may be related to the stage of development, the openness of the economy, the variability of output, social fragmentation, population structure and institutional and cultural aspects of society. If growth regressions continue to have policy variables on the right-hand side, special efforts should be made to find suitable instrumental variables to avoid biased policy variable coefficients.

Econometrically, most studies ignore the spatial configuration of the growth process. Regions or countries are often treated as non-spatial units of observation. While panel data analysis may control for the possibility of cross-sectional heteroscedasticity, time-wise auto regression, simultaneity and endogeneity, the possibility of spatial autocorrelation is rarely acknowledged.

Given that the government spending and social security systems in the EU and the US are quite different, it is relevant for future research to divide the developed-country sample into an EU sample and US sample. So far, only three categories of developed country samples are used in the literature, OECD countries, EU countries and a mixture of developed countries. Additionally, more attention should be paid to examining the issue of a non-linear relationship between government spending and growth, as neglecting a non-linear relationship could lead to model misspecification and biased empirical analysis. We found that a major limitation in the literature is the absence of control for a non-linear relationship between government spending and growth.

In recent years, the emphasis of the research of fiscal policy on growth has moved from the traditional fiscal policy variables to externalities, competition policy, monetary policy, property rights, institutions and law and order. Given the growing popularity of meta-analysis in economics and the growing ease by which new research findings are quickly distributed worldwide, meta-analysis of such topics could be a fruitful endeavour in the future. 


\section{References}

Abdel-Rahman, A.M.M. \& Barry, Z. 1997, "Public Investment, Government Concumption and Wagner's Law in Oil Rich Economy: Study in Cointegration and Structural Breaks", Studi Economici, vol. 63, pp. 141-158.

Abdullah, H. \& Maamor, S. 2010, "Relationship between National Product and Malaysian Government Development Expenditure: Wagner's Law Validity Application", International Journal of Business and Management, vol. 5, no. 1, pp. 88-97.

Abizadeh, S. \& Gray, J. 1985, "Wagner's Law: A pooled time-series cross-section comparison", National Tax Journal, vol. 88, pp. 209-218.

Abizadeh, S. \& Yousefi, M. 1998, "An Empirical Analysis of South Korea's Economic Development and Public Expenditure Growth", Journal of Socio-Economics, vol. 27, pp. 687-700.

Abizadeh, S. \& Yousefi, M. 1988, "An Empirical Re-Examination of Wagner's Law", Economic Letters, vol. 26, pp. 169-173.

Abul Kalam, M. \& Aziz, N. 2009, "Growth of Government Expenditure in Bangladesh: An Empirical Enquiry into the Validity of Wagner's Law", Global Economy Journal, vol. 9, no. 2, pp. 1-20.

Afxentiou, P.C. 1986, "Wagner's law: The experience of Cyprus", Economic Notes, vol. 2, pp. 158-172.

Afxentiou, P.C. \& Serletis, A. 1996, "Government expenditures in the European Union: Do they converge or follow Wagner's Law?", International Economic Journal, vol. 10, pp. 33-47.

Afzal, M. \& Abbas, Q. 2010, "Wagner's law in Pakistan: Another look", Journal of Economics and International Finance, vol. 2, no. 1, pp. 12-19.

Ageli, M.M. 2013, “Wagner's Law in Saudi Arabia 1970 - 2012: An Econometric Analysis, Asian Economic and Financial Review, vol. 3, no.5, pp. 647-659.

Agell, J., Lindh, T. \& Ohlsson, H., 1999, "Growth and the public sector: a reply", European Journal of Political Economy, vol. 15, pp. 359-366.

Agorastos, K., Varelas, E. \& Kostopoulos, T. 1998, "Regional Differences between North and South Greece at the turn of the century", ERSA conference papers ersa98p105, European Regional Science Association, .

Ahmad, N. \& Ahmed, F. 2005, "Does government size matter? A Case Study of D-8 Member Countries", Pakistan Economic and Social Review, vol. 2, pp. 199-212.

Ahsan, S.M., Kwan , A. C. C. \& Sahni, B.S. 1996, "Cointegration and Wagner's Hypothesis: Time Series Evidence for Canada", Applied Economics, vol. 28, pp. 1055-1058.

Akitoby, B., Clements, B., Gupta, S. \& Inchauste, G. 2006, "Public spending, voracity, and Wagner's law in developing countries", European Journal of Political Economy, vol. 22, pp. 908-924.

Al- Faris, A.F. 2002, "Public expenditure and economic growth in the Gulf Cooperation Council countries", Applied Economics, vol. 34, pp. 1187-1193.

Albatel , A.H. 2002, "Wagner's Law and the Expanding Public Sector in Saudi Arabia", Administrative Sciences, vol. 14, no. 2, pp. 139-156.

Al-Hasoon, I.M.A. 2005, Estimating the relationship between GDP growth and government spending in four GCC countries: A comparison of GDP and non-oil GDP growth, Colorado State University.

Alimi, R.S. 2014, “Testing Augmented Wagner's Law for Nigeria Based On Cointegration and Error-Correction Modelling, The Social and Management Scientists, vol. 7, no. 1, pp. 11-24.

Alleyne, D. 1999, "Testing for Wagner's Law in Jamaica, Guyana, Barbados and Trinidad Tobago: Is There Spurious Relationship?", Social and Economic Studies, vol. 48, pp. 121-135.

Al-Obaid, H.A. 2004, Rapidly Changing Economic Environments and the Wagner's Law: the case of Saudi Arabia, Colorado State University.

Alptekin, A. \& Levine, P. 2012, “Military expenditure and economic growth: a meta-analysis", European Journal of Political Economy, vol. 28, pp. 636-650.

Ansari, M.I., Gordon, D.V. \& Akuamoah, C. 1997, "Keynes versus Wagner: Public expenditure and national income for three African countries", Applied Economics, vol. 29, pp. 543-550.

Antoniou, A., Katrakilidis, C. \& Tsaliki, P. 2013, “Wagner's Law versus Keynesian Hypothesis: Evidence from pre-WWII Greece", Panoeconomicus, vol. 4, pp. 457-472.

Arpaia, A. \& Turrini, A. 2008, "Government expenditure and economic growth in the EU: long run tendencies and short-term adjustments", Economic Papers 300, European Economy, .

Ashworth, J. 1994, "Spurious in Mexico: A Comment on Wagner's Law", Public Finance, vol. 49, pp. 282-286.

Asseery, A.A., Law, D. \& Perdikis, N. 1999, "Wagner's Law and Public Expenditure in Iraq: A Test Using Disaggregated Data", Applied Economics Letters, vol. 63, pp. 39-44. 
Awaworyi Churchill, S., Ugur, M. \& Yew, S.L. 2017, “Does government size affect per-capita income growth? A hierarchical meta-regression analysis" Economic Record, vol. 93, pp. 142-171.

Babatunde, M.A. 2008, "A Bound Testing Analysis of Wagner's Law in Nigeria: 1970-2006", Conference Paper, presented at African Econometric Society, 13th Annual conference on econometric modeling in Africa 9-11 July 2008, University of Pretoria, South Africa, .

Bagdigen, M. \& Cetintas, H. 2003, "Causality between Public Expenditure and Economic Growth: The Turkish Case", Journal of Economic and Social Research, vol. 6, no. 1, pp. 53-72.

Bairam, E.I. 1995, "Level of Aggregation, Variable Elasticity and Wagner's Law", Economic Letters, vol. 48, pp. 341-344.

Bairam, E.I. 1992, "Variable Elasticity and Wagner's Law", Public Finance, vol. 47, pp. 491-495.

Bashirli, S. \& Sabiroglu, I.M. 2013, "Testing Wagner's Law in an Oil-Exporting Economy: the Case of Azerbaijan", Transition Studies review, vol. 20, no. 3, pp. 295-307.

Bergh, A. \& Henrekson, M. 2011, "Government size and growth: a survey and interpretation of the evidence", Journal of Economic Surveys, vol. 25, pp. 872-897.

Bird, R.M. 1971, "Wagner's Law of expanding state activity", Public Finance, vol. 26, pp. 1-26.

Biswal, B., Dhawan, U. \& Lee, H.Y. 1999, "Testing Wagner versus Keynes using disaggregated public expenditure data for Canada", Applied Economics, vol. 31, pp. 1283-1291.

Bohl, M.T. 1996, "Some international evidence on Wagner's law", Public finance, vol. 51, pp. 185-200.

Burney, N.A. 2002, "Wagner's hypothesis: evidence from Kuwait using cointegration tests", Applied Economics, vol. 34, pp. 49-57.

Cavusoglu, A.T. 2005, "Testing the validity of Wagner's law in Turkey: the bounds testing approach", The Review of Political Sciences of Ankara University, vol. 60, no. 1, pp. 73-78.

Chang, T. 2002, "An econometric test of Wagner's Law for six countries based on cointegration and errorcorrection modelling techniques", Applied Economics, vol. 34, pp. 1157-1169.

Chang, T.W., Liu, W. \& Caudill , S.B. 2004, "A re-examination of Wagner's Law for ten countries based on cointegration and error-correction modelling techniques", Applied Financial Economics, vol. 14, pp. 577-589.

Chletsos, M. \& Kollias, C. 1997, "Testing Wagner's Law Using Disaggregated Public Expenditure Data in the Case of Greece: 1953-1993", Applied Economics, vol. 29, pp. 371-377.

Chow, Y.F., Cotsomitis, J.A. \& Kwan, C.C. 2002, "Multivariate Cointegration and Causality tests of Wagner's hypothesis: evidence from the UK", Applied Economics, vol. 34, pp. 1671-1677.

Courakis, A.S., Moura-Roque F. \& Tridimas G. 1993, "Public expenditure growth in Greece and Portugal, Wagner's Law and beyond", Applied Economics, vol. 25, pp. 125-134.

Dao, M.Q. 1995, "Government Consumption and Economic Growth in Middle-Income Economies", Journal for Studies in Economic and Econometrics, vol. 19, pp. 1-11.

Dar, A.A. \& Amirkhalkhali, S. 2002, "Government Size, Factor Accumulation, and Economic Growth: Evidence from OECD Countries", Journal of Policy Modelling, vol. 24, pp. 679-692.

Demirbas, S. 1999, "Co-integration Analysis-Causality Testing and Wagner's Law: The Case of Turkey, 19501990", Discussion Papers in Economics, Department of Economics, University of Leicester, UK. .

Dilrukshini, W.A. 2004, "Public Expenditure and Economic Growth in Sri Lanka: Cointegration Analysis and Causality Testing", Staff studies, Central Bank of Sri Lanka, vol. 34, no. 1-2, pp. 51-68.

Dogan, E. \& Tang, T.C. 2006, "Government expenditure and national income: causality tests for five South East Asian countries", International Business and Economics Research Journal, vol. 5, pp. 49-58.

Dolenc, P. 2009, "Wagner's Law is still applicable: Empirical Evidence For Slovenia", Original Scientific Papers 56.

Dritsakis, N. \& Adamopoulos, A. 2004, "A causal relationship between government spending and economic development : an empirical examination of the Greek economy", Applied Economics, vol. 36, pp. 457-464.

Ferris, J.S. \& West, E.G. 1996, "Testing Theories of Real Government Size: U.S. Experience, 1959-89", Southern Economic Journal, vol. 62, pp. 537-553.

Florio, M. \& Colautti, S. 2005, "A logistic growth theory of public expenditures: A study of five countries over 100 years", Public Choice, vol. 122, pp. 355-393.

Gandhi, V.P. 1971, "Wagner's law of public expenditure: Do recent cross-section studies confirm it?", Public Finance, vol. 26, pp. 44-56.

Georgakopoulos, T., Kintis, A. \& Loizides, I. 1992, "Public sector growth: modelling intertemporal government behaviour", Cyprus Journal of Economics, vol. 5, pp. 96-109.

Georgakopoulos, T. \& Loizides, I. 1994, "The growth of the public sector: Tests of alternative hypotheses with data from Greece", Cyprus Journal of Economics, vol. 7, pp. 12-29. 
Ghamdi, A.M. 1983, Public expenditure in Saudi Arabia: testing Wagner's Law and critical appraisal of development, Colorado State University.

Ghartey, E.E. 2008, "The budgetary process and economic growth: Empirical evidence of the Jamaican economy", Economic Modelling, vol. 25, pp. 1128-1136.

Goffman, J.J. \& Mahar, D.J. 1971, "The growth of public expenditures in selected developing nations: Six Caribbean nations", Public Finance, vol. 26, pp. 57-74.

Grenade K. \& Wright, A. 2013, "Public Spending in Selected Caribbean Countries: Testing Wagner's Law and the Ratchet Hypothesis", Public Finance Review, vol. 42, pp. 487-510.

Guerrero, F. \& Parker, E. 2007, "The Effect of Federal Government Size on Long-Term Economic Growth in the United States, 1792-2004 ", UNR Economics Working Paper Series Working Paper No. 07-002, .

Gupta, S.P. 1967, "Public expenditure and economic growth; a time series analysis", Public Finance, vol. 22, pp. 423-461.

Gyles, A.F. 1991, "A Time-Domain Transfer Function Model of Wagner's Law: The Case of the United Kingdom Economy", Applied Economics, vol. 23, pp. 327-330.

Halicioglu, F. 2003, "Testing Wagner's Law for Turkey, 1960-2000", Review of Middle East Economics and Finance, vol. 1, no. 2, pp. 129-141.

Hayo, B. 1994, "No further evidence of Wagner's Law for Mexico", Public Finance, vol. 49, pp. 287-294.

Henrekson, M. 1993, "Wagner's Law -A spurious relationship", Public Finance, vol. 48, pp. 406-415.

Hondroyiannis, G. \& Papapetrou, E. 1995, "An examination of Wagner's Law for Greece: A cointegration analysis", Public Finance, vol. 50, pp. 67-79.

Ighorado, C.A.U. \& Oriakhi, D.E. 2010, "Does the relationship between government expenditure and economic growth follow Wagner's Law in Nigeria?", Annals of the University of Petroşani, Economics, vol. 10, no. 2, pp. 185-198.

Iniquez-Montiel, A.J. 2010, "Government Expenditure and National Income in Mexico: Keynes versus Wagner", Applied Economics Letters, vol. 17, no. 887, pp. 893.

Islam, A.M. 2001, "Wagner's Law revisited: Cointegration and exogeneity tests for the USA", Applied Economics Letters, vol. 8, pp. 509-515.

Iyare, S.O. \& Lorde, T. 2004, "Co-integration, causality and Wagner's law: tests for selected Caribbean countries", Applied Economics Letters, vol. 11, pp. 815-825.

Ju Huang, C. 2006, "Government Expenditures in China and Taiwan: Do They Follow Wagner's Law?", Journal of Economic Development, vol. 31, no. 2, pp. 139-148.

Karagianni, S. \& Pempetzoglou, M. 2009, Journal of Applied Business Research, vol. 25, no. 1, pp. 69-82.

Karagianni, S., Pempetzoglou, M. \& Strikou, S. 1998, "Testing Wagner's Law for the European Union Economies", The Journal of Applied Business Research, vol. 18, pp. 107-114.

Katrakilidis, C. \& Tsaliki, P. 2009, "Further evidence of causal relationship between government spending and economic growth: the case of Greece, 1958-2004", Acta Economica, vol. 59, no. 1, pp. 57-78.

Kesavarajah, M. 2012 “Wagner's Law in Sri Lanka: An Econometric Analysis," ISRN Economics, vol. 2012, pp. 18.

Khan, A.H. 1990, "Wagner's Law and the Developing Economy: A Time Series Evidence from Pakistan", The Indian Economic Journal, vol. 38, no. 1, pp. 115-123.

Kolluri, B.R., Panik, M.J. \& Sullivan, J.J. 1989, "Wagner's Law of Public Expenditure Re-Visited", The Journal of Economics, vol. 15, pp. 98-104.

Kolluri, B.R., Panik, M.J. \& Wahab, M.S. 2000, "Government Expenditure and Economic Growth: Evidence from G7 Countries", Applied Economics, vol. 32, pp. 1059-1068.

Kolluri, B. \& Wahab, M. 2007, "Asymmetries in the conditional relation of government expenditure and economic growth", Applied Economics, vol. 39, pp. 2303-2322.

Koop, G. \& Poirier, D.J. 1995, "An Empirical Investigation of Wagner's Hypothesis by Using a Model Occurrence Framework", Journal of the Royal Statistical Society.Series A (Statistics in Society), vol. 158, no. 1, pp. pp. 123-141.

Kumar, S., Webber, D.J. \& Fargher, S. 2009, "Wagner's Law Revisited: Cointegration and Causality tests for New Zealand", Discussion Papers 0917, University of the West of England, Department of Economics, .

Lall, S. 1969, "A Note on Government Expenditures in Developing Countries", The Economic Journal, vol. 79, pp. 413-417.

Lamartina, S. \& Zaghini, A. 2008, "Increasing Public Expenditures: Wagner's Law in OECD Countries", Center for Financial Studies Working Papers, vol. 13.

Legrenzi, G. \& Milas, C. 2002, "The Role of Omitted Variables in Identifying a Long-Run Equilibrium Relationship for the Italian Government Growth", International Tax and Public Finance, vol. 9, pp. 435-449. 
Lin, C.A. 1995, "More evidence on Wagner's Law for Mexico", Public Finance, vol. 50, no. 2, pp. 262-277.

Liu, J., Chang, T., Hong Ho, Y. \& Ju Huang, C. 2005, "An Empirical Note on Testing Wagner's Law for China: 19792002", The Business Review, vol. 3, no. 2, pp. 131-134.

Liu, L.C., Hsu, C.E. \& Younis, M. 2008, "The Association between government expenditure and economic growth: Granger causality test of US data, 1947-2002", Journal of Public Budgeting, Accounting and Financial Management, vol. 20, no. 4, pp. 537-553.

Loizides, I. \& Vamvoukas, G. 2005, "Government expenditure and economic growth: Evidence from trivariate causality testing", Journal of Applied Economics, vol. 8, pp. 125-152.

Magazzino, C. 2010a, "Wagner's Law and Augmented Wagner's Law in EU-27, A time-series analysis on stationarity, cointegration and causality ", C.R.E.I. Working Papers, , no. 5.

Magazzino, C. 2010b, "Wagner's Law" in Italy: Empirical Evidence from 1960 to 2008", Global and Local Economic Review, vol. 14, no. 1, pp. 91-116.

Mann, A.J. 1980, "Wagner's law: an econometric test for Mexico 1926-1976", National Tax Journal, vol. 33, pp. 189-201.

Menyah K. \& Wolde-Rufael Y. 2012, "Wagner's Law Revisited: A note from South Africa”, South African Journal of Economics, vol. 80, no. 2, pp. 200-208.

Michas, N.A. 1975, "Wagner's Law of Public Expenditures: What Is the Appropriate Measurement for a Valid Test?", Public Finance, vol. 30, pp. 77-85.

Michas, N.A. 1974, "Application of Covariance Analysis to Public Expenditure Studies", Finanzarchiv, vol. 32, pp. 295-304.

Murthy, N.R.V. 1994, "Wagner's Law, spurious in Mexico or misspecification: a reply", Public Finance, vol. 49, pp. 295-303.

Murthy, N.R.V. 1993, "Further evidence of Wagner's law for Mexico: An application of cointegration analysis", Public finance, vol. 48, pp. 92-96.

Mutuku, C. \& Kimani D. 2012, “Investigating Wagner's law-cointegration and causality tests for Kenya”. Current Research Journal of Economic Theory, vol. 4, no. 2, pp. 43-52.

Nagarajan, P. \& Spears, A. 1990, "An econometric test of Wagner's Law for Mexico: a re-examination", Public Finance, vol. 45, pp. 165-168.

Narayan, P., Prasad, A. \& Singh, B. 2008, "A test of the Wagner's hypothesis for the Fiji islands", Journal of Applied Economics, vol. 40, no. 21, pp. 2793-2801.

Narayan, P.K., Nielsen, I. \& Smyth, R. 2008, "Panel Data, cointegration, causality and Wagner's Law: Empirical evidence from Chinese provinces", China Economic Review, vol. 19, no. 2, pp. 197-207.

Nijkamp, P. \& Poot, J. 2004, "Meta-analysis of the effect of fiscal policies on long-run growth", European Journal of Political Economy, vol. 20, pp. 91-124.

Njimanted, G.F. 2012, “An Econometric Investigation into the Wagner's Law in the Cameroon Economy: The Vector Auto-Regressive Approach", Journal of the Cameroon Academy of Sciences, vol. 10, no. 1, pp. 4760.

Nomura, M. 1995, "Wagner's hypothesis and displacement effect in Japan, 1960-1991", Public Finance, vol. 50, no. 1 , pp. 121-135.

Oteng-Abayie, E.F. 2011, "Government Expenditure and Economic Growth In Five ECOWAS Countries: A Panel Econometric Estimation", Journal of Economic Theory, vol. 5, no. 1, pp. 11-14.

Oxley, L. 1994, "Cointegration, causality and Wagner's law: A test for Britain 1870-1913", Scottish Journal of Political Economy, vol. 41, pp. 286-297.

Pahlavani, M., Abed, D. \& Pourshabi, F. 2011, "Investigating the Keynesian view and Wagner's Law on the size of Government and Economic Growth in Iran", International Journal of Business and Social Science, vol. 2, no. 13, pp. 170-175.

Paparas, D., Richter, C., and Paparas, A. 2015a, "Fiscal Policy and Economic Growth, Empirical Evidence in European Union", Turkish Economic Review Vol 2, Issue 4, pp. 152-182.

Paparas, D., Richter, C., and Paparas, A. 2015b, "A Synthesis of Empirical Research in the Sustainability of Fiscal Policy", Journal of Economics Bibliography Vol 2, Issue 4, pp. 106-125.

Paparas, D, and Richter, C. 2018, "The validity of Wagner's Law in the United Kingdom during the Last Two Centuries", International Economics and Economic Policy, Forthcoming

Payne, J.E. \& Ewing , B.T. 1996, "International evidence on Wagner's hypothesis: A cointegration analysis", Public Finance, vol. 51, pp. 258-274.

Permana, Y.H. \& Wika, G.S. 2014, "Testing the Existence of Wagner Law and Government Expenditure Volatility in Indonesia Post-Reformation Era", Journal of Economics and Sustainable development, vol. 5, no. 10, pp. 130-139. 
Peters, A. 2002, "An Application of Wagner's 'law' of Expanding State Activity to Totally Diverse Countries", Transition, , no. 31.

Priesmeier, P. \& Koester, G. B. 2012, “Does Wagner's law ruin the sustainability of German public finances?”, Discussion Paper Deutsche Bundesbank, No 08/2012.

Poot, J., 2000, "A synthesis of empirical research on the impact of government on long run growth", Growth Change, vol. 31, pp. 516-546.

Ram, R. 1992, "Use of Box-Cox Models for Testing Wagner's Hypothesis: A Critical Note", Public Finance, vol. 47, pp. 496-504.

Ram, R. 1987, "Wagner's hypothesis in time series and cross section perspectives: evidence from "real" data for 115 countries", The review of Economics and Statistics, vol. 69, pp. 194-204.

Ram, R. 1986, "Government size and economic growth: A new framework and some evidence from cross-section and time-series data", American Economic Review, vol. 76, no. 1, pp. 191-203.

Rehman, H.U., Ahmed, I. \& Awan, M.S. 2007, "Testing Wagner's Law For Pakistan: 1972-2004", Pakistan Economic and Social Review, vol. 45, no. 2, pp. 155-166.

Richter, C. \& Paparas, D. 2012, “The Validity of Wagner's Law in the United Kingdom for the period 1850-2010", INFER Working paper no 2012.9, Münster.

Richter, C. \& Paparas, D. 2013a, "The Validity of Wagner's Law in Greece during the Last Two Centuries", Applied Economics Quarterly, vol. 59, no. 4, pp. 331-360.

Richter, C. and Paparas, D. 2013b, "How Reliable are Budget Sustainability Tests? A Case Study for Greece", International Journal of Public Policy, vol, 9(1/2), p. 23-43.

Samudram, M., Nair, M. \& Vaithilingam, S. 2009, "Keynes and Wagner on government expenditures and economic development: the case of a developing economy", Empirical Economics, vol. 36, pp. 697-712.

Shelton, C.A. 2007, "The size and composition of government expenditure", Journal of Public Economics, vol. 91, pp. 2230-2260.

Sideris, D. 2007, "Wagner's Law in 19th Century Greece: A Cointegration and Causality Analysis", Bank of Greece Working Papers, vol. 64.

Singh, B. \& Sahni, B.S. 1984, "Causality between Public Expenditure and National Income", The Review of Economics and Statistics, vol. 66, pp. 630-644.

Sinha, D. 1998, "Government expenditure and economic growth in Malaysia", Journal of Economic Development, vol. 23, pp. 71-80.

Slemrod, J. 1995, "What Do Cross-Country Studies Teach About Government Involvement, Prosperity, and Economic Growth?", Brookings Papers on Economic Activity, vol. 2, pp. 373-431.

Tang, T.C. 2010, "Wagner's Law Versus Keynesian Hypothesis In Malaysia: An Impressionistic View", International Journal of Business and Society, vol. 11, no. 2, pp. 87-96.

Thorn, R.S. 1972, "The Evolution of Public Finances During Economic Development" in Rotterdam University Press, , pp. 187-207.

Thornton, J. 1999, "Cointegration, Causality and Wagner's Law in 19th Century Europe", Applied Economic Letters, vol. 6, no. 7, pp. 413-416.

Vatter, H.G. \& Walker, J.F. 1986, "Real Public Sector Employment Growth, Wagner's Law, and Economic Growth in the United States", Public Finance, vol. 41, pp. 116-138.

Verma, S. \& Arora, R. 2010, "Does the Indian Economy Support Wagner's Law? An Econometric Analysis", Eurasian Journal of Business and Economics, vol. 3, no. 5, pp. 77-91.

Wagner, R.E. \& Weber, W.E. 1977, "Wagner's Law, fiscal institutions and the growth of government", National Tax Journal, vol. 30, pp. 59-68.

Wahab, M. 2004, "Economic growth and government expenditure: evidence from a new test specification ", Applied Economics, vol. 36, pp. 2125-2135.

Yay, T. \& Tastan, H. 2009, "Growth of public expenditures in Turkey during the 1950-2004 period: an econometric analysis", Romanian Journal of Economic Forecasting, vol. 12, no. 4, pp. 101-118.

Yousefi, M. \& Abizadeh, S. 1992, "Growth of state government expenditures: Empirical evidence from the United States", Public Finance, vol. 47, pp. 322-339.

Yuk, W. 2005, "Government Size And Economic Growth: Time-Series Evidence For The United Kingdom, 18301993", Econometrics Working Paper EWP0501, .

Zheng, Y., Li, J., Wang, X. \& Li, C. 2010, "An Empirical Analysis of the Validity of Wagner's Law in China A Case Study Based on Gibbs Sampler", Journal of Business and Management, vol. 5, no. 6, pp. 161-168. 
23 | P a g e 